\title{
A Study on Factors Affecting the Mobile Learning of Undergraduate Students in China
}

\author{
Degang Lai, Chun Mao* \\ Southwest University, Chongqing, China \\ Email: "
}

Received 26 March 2014; revised 26 April 2014; accepted 2 May 2014

Copyright (C) 2014 by authors and Scientific Research Publishing Inc.

This work is licensed under the Creative Commons Attribution International License (CC BY).

http://creativecommons.org/licenses/by/4.0/

c) (i) Open Access

\begin{abstract}
There are many factors affecting the mobile learning of undergraduate students. This paper adopts the structure of close-ended and the Likert-Scale five-point measure questionnaire. We choose 300 undergraduate students as the respondents, and they all come from 4 universities in Chongqing. The result indicates: 1) Infrastructure construction of the mobile network in universities is very good, more than $\mathbf{7 0 \%}$ of schools open the WIFI to all of the students; 2 ) The self-efficacy of mobile learning of undergraduate students is very high, more than $96 \%$ of the respondents use Mobile Phone to link to internet, and most of them think that they have the ability to use mobile devices and mobile learning; 3) Encouragements from teachers, classmates and friends are unsatisfactory, only $25.4 \%$ of the respondents agree with the item "The teacher has been encouraged me to use mobile learning" (10.3\% strongly agree, $15.1 \%$ agree, $M=2.84) ; 4)$ The fee of using mobile devices should be decreased to meet students' learning, only $19.5 \%$ of respondents agree with the item "The charge of using mobile devices is cheap for me" $(4.4 \%$ strongly agree, $15.1 \%$ agree, $M=2.70$ ).
\end{abstract}

\section{Keywords}

Mobile Learning; M-Learning; Undergraduate Students

\section{Introduction}

Mobile devices, such as multimedia-enabled Mobile Phones and tablet PCs, are personal, portable and being increasingly used to assist students' learning. Mobile learning (or m-learning), which means learning through mo-

"Corresponding author. 
bile devices, allows students to study anywhere and at any time. Mobile learning is opening new possibilities for personal fulfillment and lifelong learning (Sharples, 2005). Adopting mobile technologies in Higher Education could create powerful opportunities to support called here and now learning and learners have the chance to access information anytime and anywhere to perform authentic activities in the context of their learning (Shishah, 2013; Martin, 2013).

In 2012, the Ministry of Education of the People's Republic of China released Education Informatization Ten Year Development Plan (2011-2020). The plan claims that informatization is an effective way to improve the quality of higher education. According to the plan, we should innovate undergraduate students' learning style based ICT. In order to meet the demands of education innovation and the development of ICT, a number of researches have been carried out about undergraduate students' mobile learning. Research on mobile leaning in China began in 2000, introduced by DR. Desmond Keegan, and is at the phase of reflective development, focusing on theoretical research (Wang \& Wang, 2013; Miao \& Pan, 2012). Some researchers designed Mobile Learning Environment and practiced mobile learning in several courses, such as English, Math, Database Theory, and so on (Ji \& Xie, 2012; Wang \& Huang, 2013; Zhang \& Huang, 2013). Several studies have focused on the impacts of demographic factors in undergraduate students' mobile usage, such as gender, finance, and using time on mobile phone (Mo \& Zhang, 2012). In addition, other studies emphasized the impacts of teachers on mobile learning (Liu \& Wu, 2011; Liu \& Liu, 2013).

\section{Methodology}

This study adopts the structure of close-ended and the Likert-Scale five-point measure questionnaire. Each item is given a 5 -point scale with $1=$ strongly disagree, $2=$ disagree, $3=$ slightly agree, $4=$ agree, and $5=$ strongly agree. Each questionnaire took 20 - 25 minutes to complete. The questionnaire was developed in Chinese. We chose 300 undergraduate students as the respondents. All of them came from 4 universities in Chongqing: Southwest University, Chongqing University of Technology, Chongqing University of Arts and Sciences, and Chongqing Normal University. Data for the investigation were collected for 2 weeks. The questionnaires were randomly delivered to students from different majors and grades. We hand out 75 questionnaires in each college, 300 questionnaires in total in 4 colleges. Recall 287 questionnaires, 272 questionnaires were available.

\section{Results}

\subsection{Descriptive Statistics}

There are 145 males and 127 females. The respondents for ways linking to internet are presented in Table 1 , while for the time on the internet one day shown in Table 2.

\subsection{Factors Affecting the Mobile Learning of Undergraduate Students}

Table 3 displays the results of statements regarding factors affecting the mobile learning of undergraduate students. The mean score for each item was used to describe the strength of each item. There are four items' mean scores higher than 3, and there are six items' mean scores lower than 3 . The item "I believe that I can use mobile devices and surf on the internet freely" recorded the highest mean score $(M=4.05)$. The second highest mean score is "There are special services offered to students to use mobile devices in my area" $(M=3.64)$, followed by "I believe that using mobile learning resources is very easy" $(\mathrm{M}=3.48)$ and "My university opens the Wi-Fi to every student" $(\mathrm{M}=3.35)$. The lowest mean score is item "Teacher has been assigned works or tasks finished through mobile learning” ( $\mathrm{M}=2.17)$.

In this table, there are 272 questionnaires available, each item is given a 5-point scale with $1=$ strongly disagree, 2 = disagree, 3 = slightly agree, $4=$ agree, and $5=$ strongly agree.

\section{Discussion}

Based on the results obtained above, infrastructure construction of the mobile network in universities is very good. All schools surveyed in this research now have open campus broad-band to the students' dormitories. More than $70 \%$ of schools open the Wi-Fi to all of the students, free for campus network and charge for internet. The mean score of the item "My university opens the Wi-Fi to every student" is 3.35. At the same time, the 
Table 1. Respondents for mobile devices linking to internet (multiple-choice).

\begin{tabular}{cccc}
\hline Ways & $\begin{array}{c}\text { E-ink Book } \\
\text { (e.g. Kindle, HanWang, BamBook) }\end{array}$ & $\begin{array}{c}\text { Tablet PCs (e.g. iPad, Galaxy } \\
\text { Tab, Lenovo Pad) }\end{array}$ & $\begin{array}{c}\text { Multimedia-Enabled Mobile } \\
\text { Phone }\end{array}$ \\
\hline Number of People & 14 & 67 & 263 \\
\hline
\end{tabular}

Table 2. Respondents for time on the internet one day (single-choice).

\begin{tabular}{ccccccccc}
\hline Time (minute) & 0 & $1-30$ & $31-60$ & $61-90$ & $91-120$ & $121-150$ & $151-180$ & More than 180 \\
\hline Number of People & 0 & 12 & 85 & 80 & 53 & 26 & 9 & 7 \\
\hline
\end{tabular}

Table 3. Percentage distribution of factors affecting the mobile learning of undergraduate students.

\begin{tabular}{|c|c|c|c|c|c|c|}
\hline Item & $\begin{array}{c}\text { Strongly } \\
\text { Disagree } \\
\text { (\%) }\end{array}$ & $\begin{array}{l}\text { Disagree } \\
(\%)\end{array}$ & $\begin{array}{c}\text { Slightly } \\
\text { Agree } \\
(\%)\end{array}$ & Agree (\%) & $\begin{array}{c}\text { Strongly } \\
\text { Agree } \\
(\%)\end{array}$ & Mean \\
\hline The charge of using mobile devices is cheap for me. & $\begin{array}{c}45 \\
16.5 \%\end{array}$ & $\begin{array}{c}57 \\
21.0 \%\end{array}$ & $\begin{array}{c}117 \\
43.0 \%\end{array}$ & $\begin{array}{c}41 \\
15.1 \%\end{array}$ & $\begin{array}{c}12 \\
4.4 \%\end{array}$ & 2.70 \\
\hline $\begin{array}{l}\text { There are special services offered to students to use } \\
\text { mobile devices in my area. }\end{array}$ & $\begin{array}{c}15 \\
5.5 \%\end{array}$ & $\begin{array}{c}19 \\
7.0 \%\end{array}$ & $\begin{array}{c}87 \\
32.0 \%\end{array}$ & $\begin{array}{c}79 \\
29.0 \%\end{array}$ & $\begin{array}{c}72 \\
26.5 \%\end{array}$ & 3.64 \\
\hline $\begin{array}{l}\text { I believe that using mobile learning resources is very } \\
\text { easy. }\end{array}$ & $\begin{array}{c}23 \\
8.5 \%\end{array}$ & $\begin{array}{c}31 \\
11.4 \%\end{array}$ & $\begin{array}{c}67 \\
24.6 \%\end{array}$ & $\begin{array}{c}94 \\
34.6 \%\end{array}$ & $\begin{array}{c}57 \\
21.0 \%\end{array}$ & 3.48 \\
\hline $\begin{array}{l}\text { I believe that I can use mobile devices and surf on the } \\
\text { internet freely. }\end{array}$ & $\begin{array}{c}1 \\
0.4 \%\end{array}$ & $\begin{array}{c}7 \\
2.6 \%\end{array}$ & $\begin{array}{c}59 \\
21.7 \%\end{array}$ & $\begin{array}{c}115 \\
42.3 \%\end{array}$ & $\begin{array}{c}90 \\
33.1 \%\end{array}$ & 4.05 \\
\hline $\begin{array}{l}\text { The majority of my classmates uses mobile learning and } \\
\text { encourages me to use. }\end{array}$ & $\begin{array}{c}68 \\
25.0 \%\end{array}$ & $\begin{array}{c}97 \\
35.7 \%\end{array}$ & $\begin{array}{c}79 \\
29.0 \%\end{array}$ & $\begin{array}{c}15 \\
5.5 \%\end{array}$ & $\begin{array}{c}13 \\
4.8 \%\end{array}$ & 2.29 \\
\hline $\begin{array}{l}\text { Most of my friends use mobile learning and encourage } \\
\text { me to use. }\end{array}$ & $\begin{array}{c}64 \\
23.5 \%\end{array}$ & $\begin{array}{c}92 \\
33.8 \%\end{array}$ & $\begin{array}{c}75 \\
27.6 \%\end{array}$ & $\begin{array}{c}34 \\
12.5 \%\end{array}$ & $\begin{array}{c}7 \\
2.6 \%\end{array}$ & 2.37 \\
\hline Teacher has been encouraged me to use mobile learning. & $\begin{array}{c}32 \\
11.8 \%\end{array}$ & $\begin{array}{c}77 \\
28.3 \%\end{array}$ & $\begin{array}{c}94 \\
34.6 \%\end{array}$ & $\begin{array}{c}41 \\
15.1 \%\end{array}$ & $\begin{array}{c}28 \\
10.3 \%\end{array}$ & 2.84 \\
\hline $\begin{array}{l}\text { Teacher has been assigned works or tasks finished } \\
\text { through mobile learning. }\end{array}$ & $\begin{array}{c}91 \\
33.5 \%\end{array}$ & $\begin{array}{c}84 \\
30.9 \%\end{array}$ & $\begin{array}{c}69 \\
25.4 \%\end{array}$ & $\begin{array}{c}17 \\
6.3 \%\end{array}$ & $\begin{array}{c}11 \\
4.0 \%\end{array}$ & 2.17 \\
\hline My university opens the Wi-Fi to every student. & $\begin{array}{c}32 \\
11.8 \%\end{array}$ & $\begin{array}{c}73 \\
26.8 \%\end{array}$ & $\begin{array}{c}18 \\
6.6 \%\end{array}$ & $\begin{array}{c}66 \\
24.3 \%\end{array}$ & $\begin{array}{c}83 \\
30.5 \%\end{array}$ & 3.35 \\
\hline $\begin{array}{l}\text { There are courses on the internet can be accessed by } \\
\text { mobile devices in my university. }\end{array}$ & $\begin{array}{c}56 \\
20.6 \%\end{array}$ & $\begin{array}{c}97 \\
35.7 \%\end{array}$ & $\begin{array}{c}80 \\
29.4 \%\end{array}$ & $\begin{array}{c}31 \\
11.4 \%\end{array}$ & $\begin{array}{c}8 \\
2.9 \%\end{array}$ & 2.40 \\
\hline
\end{tabular}

mean score of the item "There are special services offered to students to use mobile devices in my area" is 3.64. These can be considered that most of the universities and colleges have the condition to implement mobile learning, at least can have a try.

The self-efficacy of mobile learning of undergraduate students is very high. Most of the students think that they have the ability to use mobile devices and mobile learning. Only 3\% of respondents disagree with the item "I believe that I can use mobile devices and surf on the internet freely", and Only 8.5\% of respondents strongly disagree with the item "I believe that using mobile learning resources is very easy". In this research, we find that 263 respondents (more than 96\%) use mobile phone to link to internet (Table 1), and they surf on the internet every day, even more, some of them spend 3 hours on the internet (Table 2).

The results also show that $64.4 \%$ of respondents disagree with the item "Teacher has been assigned works or tasks finished through mobile learning” (33.5\% strongly disagree, 30.9\% disagree, $\mathrm{M}=2.17$ ); $56.3 \%$ disagree with the item "There are courses on the internet can be accessed by mobile devices in my university" (20.6\% strongly disagree, $35.7 \%$ disagree, $M=2.40$ ). Only $25.4 \%$ of respondents agree with the item "Teacher has been encouraged me to use mobile learning” ( $10.3 \%$ strongly agree, $15.1 \%$ agree, $M=2.84)$. This is an unsatisfactory result, since teachers and school should be the guider and facilitator to instruct students attempt new styles of learning. 
Encouragements from classmates and friends have no significant contributing to the use of mobile learning among undergraduate students. More than half of the respondents disagree "My family encourage me to use ICT" (25.0\% strongly disagree and 35.7\% disagree). More than half of the respondents disagree "Most of my friends use mobile learning and encourage me to use" (27.3\% strongly agree and $37.7 \%$ agree). It was found that the undergraduate students were using mobile devices to communicate with classmates and friends, such as QQ, Wechat, micro-blog and so on. But they few exchange views about learning styles, especially about mobile learning.

Meanwhile, the fee of using mobile devices can also influence the use of mobile learning. Only $19.5 \%$ of respondents agree with the item "The charge of using mobile devices is cheap for me" (4.4\% strongly agree, $15.1 \%$ agree, $M=2.70$ ). There are three telecom service providers: China Mobile, China Unicom and China Telecom. Although they have provided special services for undergraduate students, but the charge is still high for students. Meanwhile, mobile learning may use a large amount of network flow, which means more spending.

\section{Conclusion}

Though the infrastructure construction of mobile network and undergraduate students' self-efficacy are acceptable, the overall result of factors affecting the mobile learning of undergraduate students is unsatisfactory. $60 \%$ mean scores of all items included in the questionnaire are smaller than 3 . The lowest mean score in this research is relating to teachers, which reflects the fact that there is little encouragement and motivation to use mobile learning from teachers and schools. There is still a lot of work to be done to promote the using of mobile learning. We suggest that teachers and schools should pay more energy and effort to improve the learning style and learning effect in China.

\section{Funding}

Supported by “The Fundamental Research Funds for the Central Universities” XDJK2012C105.

\section{References}

Ji, X.-H., \& Xie, J. (2012). The Research of the Database Theory Course Based on M-Learning. Computer Knowledge and Technology, 26, 38-41.

Liu, A. J., \& Liu, Z. (2013). Research on the Acceptance and Influence Factors of Mobile Learning. Open Education Research, 19, 104-111.

Liu, G. P., \& Wu, X. (2011). Analysis of Influence Factors on Acceptance of Mobile Learning for College Students in Wen Zhou. Modern Educational Technology, 21, 115-119.

Martin, F., \& Ertzberger, J. (2013). Here and Now Mobile Learning: An Experimental Study on the Use of Mobile Technology. Computers \& Education, 68, 76-85. http://dx.doi.org/10.1016/j.compedu.2013.04.021

Miao, L., \& Pan, Z. S. (2012). The Review of Domestic M-Learning Research. Modern Educational Technology, $22,23-28$.

Mo, M. F., \& Zhang, J. Q. (2012). Mobile Phone Addiction’s Influence to the College Students’ Mobile Learning and the Matching Guidance. Modern Distance Education, 14, 80-84.

Sharples, M., Taylor, J., \& Vavoula, G. (2005). Towards a Theory of Mobile Learning. Proceedings of mLearn, 1, 1-9.

Shishah, W., Hopkins, G., FitzGerald, E., \& Higgins, C. (2013). Supporting Interaction in Learning Activities Using Mobile Devices in Higher Education. QScience Proceedings: 12th World Conference on Mobile and Contextual Learning (mLearn 2013), 2013, 35. http://dx.doi.org/10.5339/qproc.2013.mlearn.35

Wang, X. C., \& Huang, R. H. (2012). Mobile Learning Service Design for Informal Learning Context. Open Education Research, 18, 16-20.

Wang, Y. M., \& Wang, J. (2013). Research Status and Future Trends of China’s Mobile Learning in Recent 20 Years. Modern Distance Education Research, 10, 49-55.

Zhang, L.-L., \& Huang, R. M. (2013). A Critical Analysis of Environment Designing for Mobile Learning. Modern Educational Technology, 23, 115-119. 